\title{
Individual Impact of Distinct Polysialic Acid Chain Lengths on the Cytotoxicity of Histone H1, H2A, H2B, $\mathrm{H} 3$ and $\mathrm{H} 4$
}

\author{
Kristina Zlatina ${ }^{1}$, Thomas Lütteke ${ }^{2,+}$ (D) and Sebastian P. Galuska ${ }^{1, *}$ \\ 1 Institute of Reproductive Biology, Leibniz Institute for Farm Animal Biology (FBN), Wilhelm-Stahl-Allee 2, \\ 18196 Dummerstorf, Germany; zlatina@fbn-dummerstorf.de \\ 2 Institute of Veterinary Physiology and Biochemistry, Justus-Liebig-University, Frankfurter Str. 100, \\ 35392 Giessen, Germany; thomas.luetteke@vetmed.uni-giessen.de \\ * Correspondence: galuska.sebastian@fbn-dummerstorf.de; Tel.: +49-38208-68-769 \\ + Current address: ITech Progress GmbH, Donnersbergweg 4, 67059 Ludwigshafen, Germany.
}

Received: 9 November 2017; Accepted: 13 December 2017; Published: 16 December 2017

\begin{abstract}
Neutrophils are able to neutralize pathogens by phagocytosis, by the release of antimicrobial components, as well as by the formation of neutrophil extracellular traps (NETs). The latter possibility is a DNA-meshwork mainly consisting of highly concentrated extracellular histones, which are not only toxic for pathogens, but also for endogenous cells triggering several diseases. To reduce the negative outcomes initiated by extracellular histones, different approaches like antibodies against histones, proteases, and the polysaccharide polysialic acid (polySia) were discussed. We examined whether each of the individual histones is a binding partner of polySia, and analyzed their respective cytotoxicity in the presence of this linear homopolymer. Interestingly, all of the histones (H1, H2A, $\mathrm{H} 2 \mathrm{~B}, \mathrm{H} 3$, and $\mathrm{H} 4$ ) seem to interact with $\alpha 2,8$-linked sialic acids. However, we observed strong differences regarding the required chain length of polySia to bind histone $\mathrm{H} 1, \mathrm{H} 2 \mathrm{~A}, \mathrm{H} 2 \mathrm{~B}, \mathrm{H} 3$, and $\mathrm{H} 4$. Moreover, distinct degrees of polymerization were necessary to act as a cytoprotective agent in the presence of the individual histones. In sum, the outlined results described polySia-based strategies to bind and/or to reduce the cytotoxicity of individual histones using distinct polySia chain length settings.
\end{abstract}

Keywords: polysialic acid; histones; neutrophil extracellular traps

\section{Introduction}

Besides other mechanisms, neutrophil extracellular traps (NETs) serve to combat pathogens, such as fungi, viruses, and bacteria. For this purpose, NETs are a meshwork of antimicrobial peptides (AMP), chromatin, and enzymes [1]. Histones that are located in the chromatin are also described to function as AMPs [2,3]. The linker histone H1, as well as the four core subunits H2A, H2B, H3, and H4 possess-like other AMPs-a positive charge and are able to bind and penetrate negatively charged cell membranes [4,5]. This ability is not only toxic for invaders, but also for host cells [6]. Interestingly, Urban and coworkers demonstrated that histones are the most abundant proteins in NETs and the concentration is significantly higher for H2A $(26.29 \%)$ and H2B (23.95\%), representing approximately $50 \%$ of the total protein fraction [7]. As already well known, histones play important roles beyond the nucleus [8]. Besides the direct cytotoxic characteristics of extracellular histones, an induction of the immune response by free extracellular histones was shown via Toll-like receptors (TLRs) TLR2 and TLR4 [9]. TLR9 instead is activated by extracellular DNA [10], and also triggers an immune response [11]. An insufficient degradation by DNases and subsequent removal of NETs through macrophages [12], or an excessive NET-formation, may lead to production of antibodies against 
histones and DNA [13], as well as to an increased activity of these pattern recognition receptors [14]. This may lead to autoimmune diseases, like systemic lupus erythematosus (SLE) [15]. DNA and histones that originated from an excessive NET formation are further associated with the development of inflammatory disorders such as thrombosis, cystic fibrosis and sepsis [16-19]. The listed examples indicate that histones are not just important for the packaging of DNA, but also belong to the innate immune system. Thus, it is of interest to identify molecules that bind histones and affect their extracellular activities.

Previous studies already showed cytoprotective effects of the polysaccharide polysialic acid (polySia) against NETs and the histones that are contained in them [20,21]. These polymers consist of $\alpha 2,8$-linked $\mathrm{N}$-acteylneuraminic acid residues, and are especially involved during the development of the brain and several other organs [22-24]. However, polySia is also present during processes of the immune system modulating, for instance, migration processes [25-30], and are often in direct neighborhood with NETs [21,31]. Although it is already known that polySia can inactivate the cytotoxic characteristics of histone-complexes in a chain length dependent manner [32], and can be used as a molecular anchor to accumulate nanoparticles on NET fibers [33], it is unknown, which one of the five histones is targeted by polySia. Until now, only undefined histone-mixtures originated from in vitro generated NETs or thymus were used $[20,21,32,33]$ including e.g., histone monomers up to octamers-as well as numerous different epigenetic modifications [34].

In the present study, we examined the cytotoxicity of each individual histone in connection with a polySia application. The histones that are used in the present study were recombinantly expressed in bacteria and lack any eukaryotic specific posttranslational modification of histones. They were applied as model-proteins to get information about the interaction between polySia and the "naked" protein backbones of the individual histones. To this end, we studied the ability of polySia with different degrees of polymerization (DP) to bind these distinct histones. The observed results demonstrated several differences in the binding capacity of polySia to the individual histones, as well as in the cytoprotective capability of polySia against the histone-mediated cytotoxicity.

\section{Materials and Methods}

\subsection{Materials}

For cell culture experiments, LPS was removed from colominic acid (Gerbu, Heidelberg, Germany) using C18 cartridges (Thermo Fisher Scientific, Dreieich, Germany), according to manufacturer specifications, as already mentioned in [33]. Used histones were: histone from calf thymus (Sigma-Aldrich, Steinheim, Germany) and recombinant human H1, H2A, H2B, H3.1, and H4 (New England Biolabs, Frankfurt am Main, Germany). All of the reagents used were of analytical grade.

\subsection{Binding Model}

The model was generated as previously described in detail [33]. The histone complex of Protein Data Bank (PDB) entry 3wa9 (PMID: 24311584) was used. The interaction of the histone complex with four polySia chains was modeled by YASARA. Different colors were attributed to the individual histones: H2A—green, H2B-cyan, H3-orange, H4-yellow. All four polySia chains are colored purple, numbered, and indicated by arrows. The location of DNA in the histone-DNA complex is shown as cords.

\subsection{Fractionation and Determination of Sialic Acid Polymers by HPLC}

For cell culture and native agarose gel experiments, $10 \mathrm{mg}$ colominic acid (Gerbu) were separated and collected according to the degree of polymerization (DP 3-15; $15-23$; 23-34; 34-46; >46), as described in detail in [32,33]. The eluents were milliQ water (E1) and $4 \mathrm{M}$ ammonium acetate buffer (E2) at a flow rate of $2.5 \mathrm{~mL} / \mathrm{min}$ with following gradient using a DNAPac PA-100 $(22 \times 250 \mathrm{~mm})$ (Thermo Fisher Scientific): t0 $\min =0 \%(v / v)$ E2, t $20 \mathrm{~min}=13 \%(v / v)$ E2, t30 $\min =17 \%(v / v)$ E2, 
$\mathrm{t} 45 \mathrm{~min}=19 \%(v / v) \mathrm{E} 2, \mathrm{t} 85 \mathrm{~min}=21 \%(v / v) \mathrm{E} 2, \mathrm{t} 110 \mathrm{~min}=100 \%(v / v) \mathrm{E} 2$. The DP of fractionized polySia was controlled, as described previously [32]. The same eluents were also used for the analytical DNAPac PA-100 column $(22 \times 250 \mathrm{~mm})$ (Thermo Fisher Scientific). Following gradient with a flow rate of $1 \mathrm{~mL} / \mathrm{min}$ was used: $\mathrm{t} 0 \mathrm{~min}=0 \% \mathrm{E} 2 ; \mathrm{t} 5 \mathrm{~min}=0 \% \mathrm{E} 2 ; \mathrm{t} 15 \mathrm{~min}=8 \% \mathrm{E} 2 ; \mathrm{t} 20 \mathrm{~min}=11 \% \mathrm{E} 2$; $\mathrm{t} 35 \mathrm{~min}=14 \% \mathrm{E} 2 ; \mathrm{t} 55 \mathrm{~min}=16 \% \mathrm{E} 2 ; \mathrm{t} 100 \mathrm{~min}=20 \% \mathrm{E} 2 ; \mathrm{t} 130 \mathrm{~min}=23 \% \mathrm{E} 2$, and $\mathrm{t} 131 \mathrm{~min}=100 \% \mathrm{E} 2$.

\subsection{Quantification of Sialic Acid Polymers by HPLC}

To determine the concentrations of fractionated sialic acids, the samples were hydrolyzed and labeled with 1,2-diamino-4,5-methylenedioxybenzene (DMB), as already described [35-37]. For hydrolysis, samples were dissolved in $0.2 \mathrm{M}$ trifluoroacetic acid (TFA) for $4 \mathrm{~h}$ at $80{ }^{\circ} \mathrm{C}$ and dried. In the next step the samples were dissolved in $80 \mu \mathrm{L}$ DMB-reaction buffer $(9 \mathrm{mM}$ sodium hydrosulfite, $0.5 \mathrm{M} \beta$-mercaptoethanol, $20 \mathrm{mM}$ TFA, $1.35 \mathrm{M} \mathrm{DMB}$ ) and were incubated at $55^{\circ} \mathrm{C}$ for $2 \mathrm{~h}$ to allow for the DMB-labeling. The addition of $20 \mu \mathrm{L} 0.2 \mathrm{~N} \mathrm{NaOH}$ stopped the reaction. The final DMB-labeled fractions were analyzed via Superspher $100 \mathrm{C}-18$ column $(250 \mathrm{~mm} \times 40 \mathrm{~mm}$, Merck-Hitachi, Darmstadt, Germany) at $40{ }^{\circ} \mathrm{C}$ by high performance liquid chromatography (HPLC) (Smartline System, Knauer, Berlin, Germany), as described in detail in [38].

\subsection{Cell Culture Experiments}

5B8 cells were cultured in Roswell Park Memorial Institute (RPMI) medium (Gibco, Darmstadt, Germany), including 10\% $(v / v)$ fetal calf serum (FCS; Thermo Fisher Scientific, Dreieich, Germany) and $1 \%$ Streptavidin at $37^{\circ} \mathrm{C}$ and $5 \% \mathrm{CO}_{2} .30,000$ cells were seeded per well on 96 -well plate in $100 \mu \mathrm{L}$ of RPMI medium, including histones or polySia, and were incubated for $1 \mathrm{~h} 40 \mathrm{~min}$ at $37{ }^{\circ} \mathrm{C}$ and $5 \%$ $\mathrm{CO}_{2}$ [32,33]. Here, the concentration of histones was $60 \mu \mathrm{g} / \mathrm{mL}$, and the concentration of Neu5Ac or fractionated sialic acid polymers was $40 \mu \mathrm{g} / \mathrm{mL}$. To determine the cytotoxicity a lactate dehydrogenase (LDH) cytotoxicity assay (BioVision, Milpitas, CA, USA) was applied.

\subsection{Agarose Gel-Electrophoresis}

Histones, polySia, and mixtures of histones with Neu5Ac or fractionated sialic acid polymers were incubated in $50 \mathrm{mM}$ Tris for $1 \mathrm{~h}$ at $30^{\circ} \mathrm{C} .1 \mu \mathrm{L}$ glycin was added and samples were loaded on a $2 \%$ agarose gel (peqLab, Erlangen, Germany) in $500 \mathrm{mM}$ Tris/ $\mathrm{HCl}, 160 \mathrm{mM}$ boric acid, $1 \mathrm{M}$ urea, $\mathrm{pH}$ 8.5. The electrophoresis was performed with a running buffer $(90 \mathrm{mM}$ Tris $/ \mathrm{HCl}, 90 \mathrm{mM}$ boric acid, $\mathrm{pH} 8.5$ ) at $80 \mathrm{~V}$ for $5-6 \mathrm{~h}$ (modified according to [39,40]). The proteins were stained with roti-blue (Roth, Karlsruhe, Germany), according to manufacturer specifications.

\subsection{Statistical Analysis}

Data sets were statistically evaluated by Student's $t$ test (unequal variances, two-tailed) by using Microsoft Excel. Significant differences are given: n.s. (not significant), $p>0.05 ;{ }^{*} p<0.05 ;{ }^{* *} p<0.01$; *** $p<0.001 ;{ }^{* * * *} p<0.0001$.

\section{Results \& Discussion}

\subsection{Binding Model between PolySia and Histones}

In a previous study [32], we already used a model of a histone-DNA-complex (Protein Data Bank entry 3wa9) and four polySia chains with a chain length of 20 sialic acid units to get a hint for possible binding areas between polySia and histone octamers. However, it was not possible to distinguish between the different histones of this octamer using the old model. Thus, the individual interaction areas of $\mathrm{H} 2 \mathrm{~A}, \mathrm{H} 2 \mathrm{~B}, \mathrm{H} 3$, and $\mathrm{H} 4$ could not be located until now.

For the current study, this model was re-evaluated to examine the role of individual histones in binding of polySia. For this purpose, the individual histones are colored differently (Figure 1). 
The model is shown from different perspectives for a better visualization of all the binding sites between polySia chains and the histones.

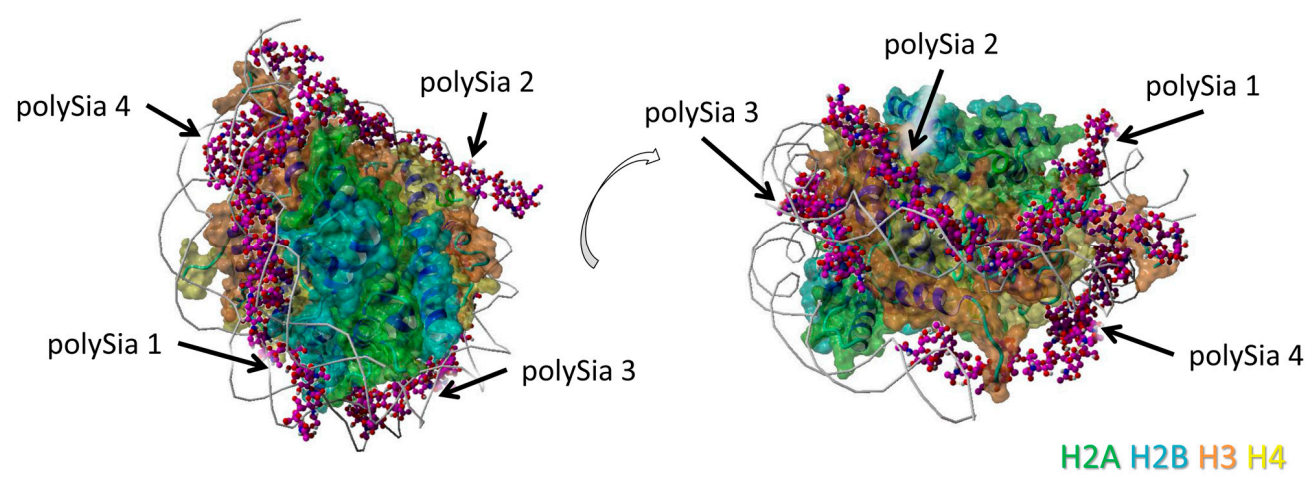

Figure 1. Model of interaction between polySia and histones. This model includes the histone-octamer of the Histone-DNA complex (Protein Data Bank entry 3wa9) as receptor and four polySia chains of 20 sialic acid units as ligands. The polySia chains are numbered and indicated by arrows. The two parts show the model from two different perspectives (rotated as shown by the open arrow). Color-code: H2A—green, H2B—cyan, H3—orange, H4-yellow, polySia-purple, DNA—gray (as cords).

We observed a particularly close neighborhood of eight successively linked sialic acid residues with H2A (Figure 2A). Here, polySia is partially colocalized with the winding of the DNA. The same polySia chain binds to the directly neighbored H2B with five successive sialic acid units. The binding area of these residues is located between those of two DNA helices (Figure 2B).

\section{A}
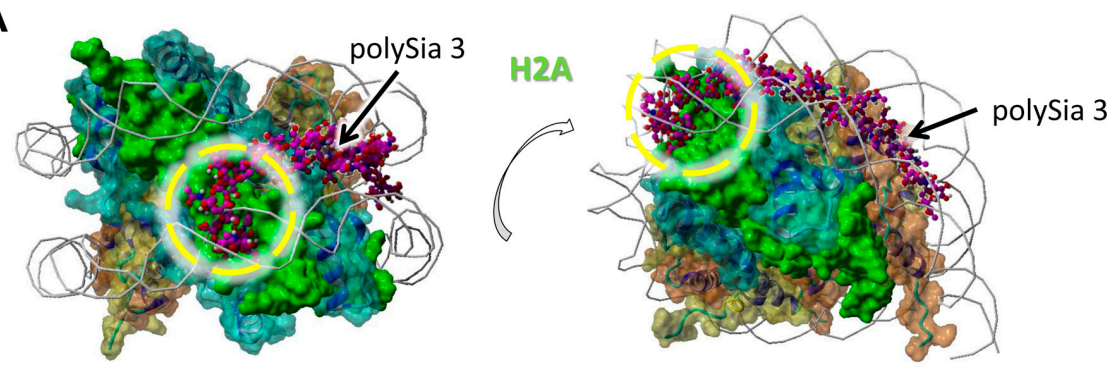

H2A H2B H3 H4
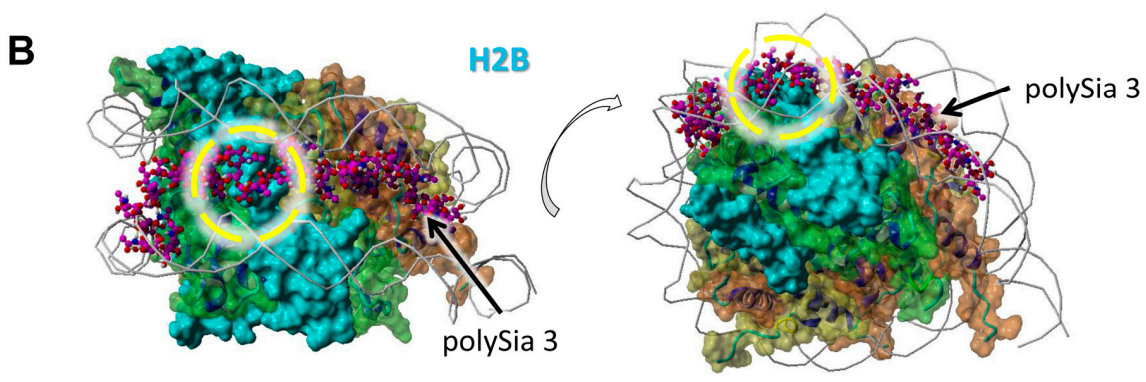

Figure 2. Model of interaction between polySia and $\mathrm{H} 2 \mathrm{~A}$ as well as H2B. The model was generated as described in Figure 1. Color-code: H2A—green, H2B-cyan, H3-orange, H4-yellow, polySia-purple, DNA - gray (as cords). Potential binding areas are highlighted by dashed circles for the histones; (A) Histone H2A, (B) Histone H2B. The numbered polySia chains are indicated by arrows. Both models are shown from two different perspectives (rotated, as shown by the open arrows). 
All four modeled polySia chains seem to bind histone H3. However, just one or two continually linked sialic acid units of these polySia chains are in close neighborhood to H3. In Figure 3A we show two of four polySia chains and in Figure 3B the remaining two. The binding areas are partially colocalized with those of DNA.

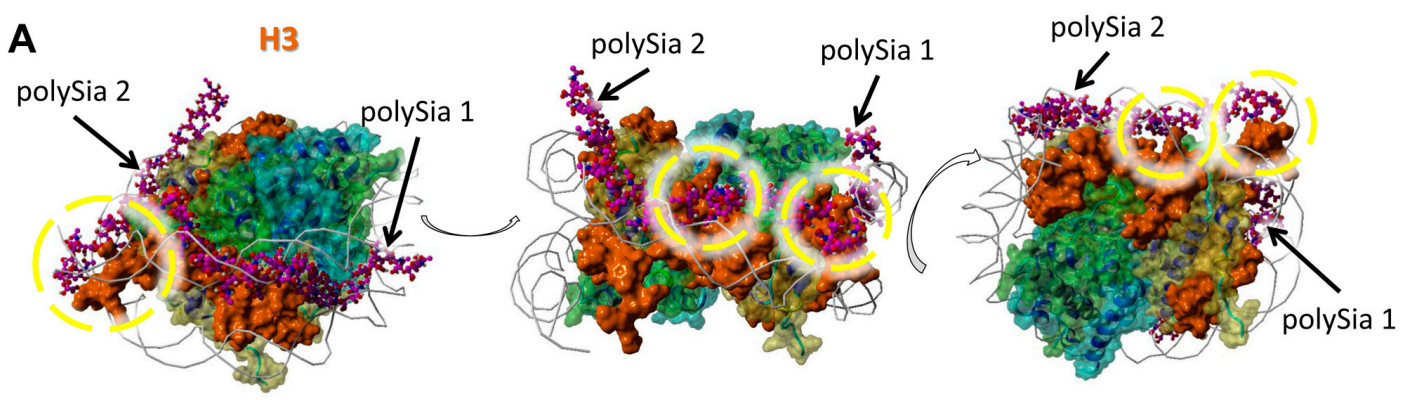

H2A H2B H3 H4

B

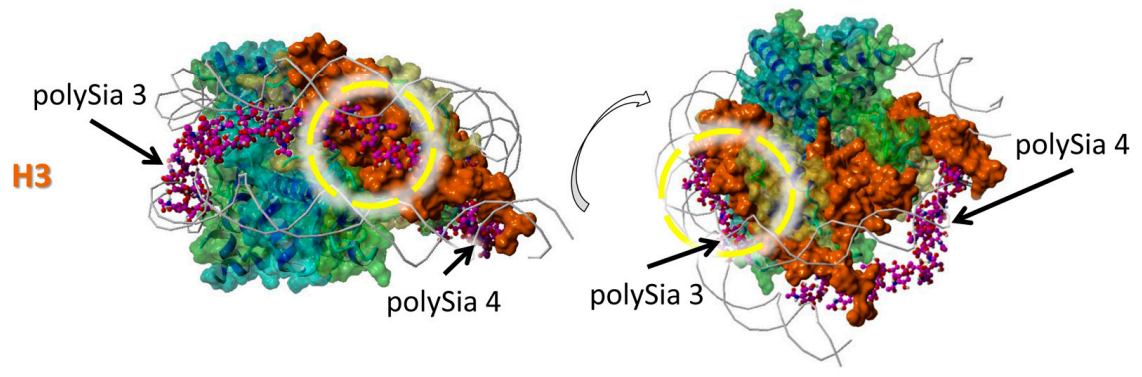

Figure 3. Model of interaction between polySia and H3. The model was generated as described in Figure 1. Color-code: H2A-green, H2B-cyan, H3-orange, H4-yellow, polySia-purple, DNA - gray (as cords). Potential binding areas are highlighted by dashed circles for the histones. The numbered polySia chains are indicated by arrows; (A) polySia chain 1 and 2, (B) polySia chain 3 and 4 . The model is shown from five different perspectives (rotated as shown by the open arrows).

H4 seems to interact with two polySia chains in total. The model shows only short distances for possible interactions between scattered sialic acid residues of the polySia chains (and not a cluster of directly linked sialic acid residues) and the protein backbone (Figure 4).
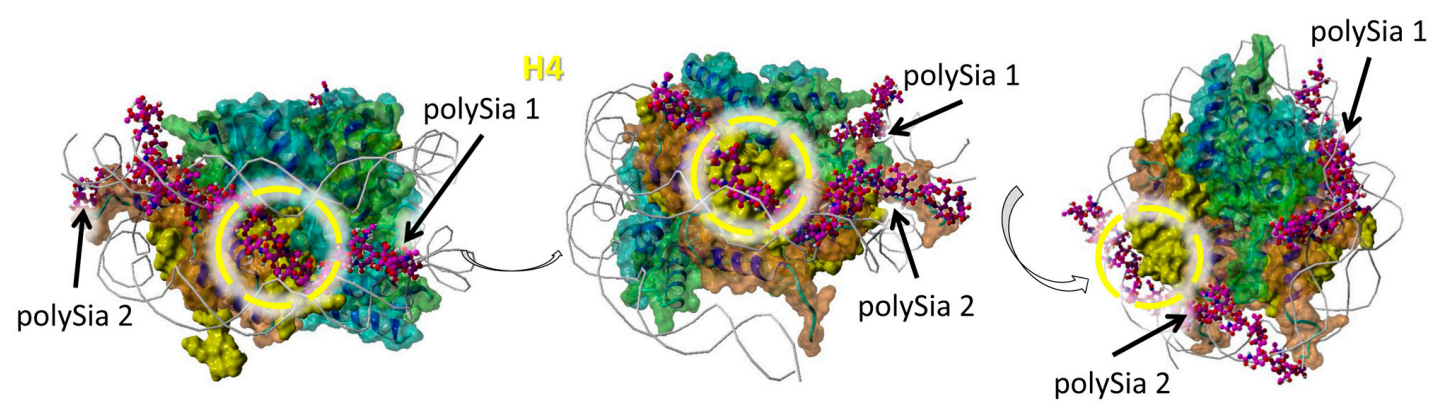

H2A H2B H3 H4

Figure 4. Model of interaction between polySia and H4. The model was generated as described in Figure 1. Color-code: H2A-green, H2B-cyan, H3-orange, H4-yellow, polySia-purple, DNA-gray (as cords). Potential binding areas are highlighted by dashed circles for the histones. The numbered polySia chains are indicated by arrows. The model is shown from three different perspectives (rotated as shown by the open arrows). 
Nevertheless, regions of all histones are covered by polySia, when H2A, H2B, H3, and H4 are present in a histone octamer. However, it has to be kept in mind that apart from these, there might be further possible interaction areas for polySia with the individual histones that are hidden by other histones as long as they build complexes. In addition, based on the variable length and flexibility of polySia there might be more potential binding motives for polySia than shown in Figures 1-4.

\subsection{PolySia Interacts with Individual Histones}

In our previous study [21,33], we demonstrated the influence of different concentrations and DPs of polySia on its binding capacity to undefined complex mixtures of different histones that originated from in vitro generated NETs and/or thymus samples. In contrast to this, in the present study, we aimed to figure out how polySia influences the characteristics of the individual histones using recombinantly expressed $\mathrm{H} 1, \mathrm{H} 2 \mathrm{~A}, \mathrm{H} 2 \mathrm{~B}, \mathrm{H} 3$ and $\mathrm{H} 4$. For this purpose, we investigated the binding capacity of polySia to histones by native agarose gel electrophoresis in a first set of experiments. The positively charged histones migrate to the negative pole under these conditions, based on their basic character (Table 1).

Table 1. Overview of the individual histone properties and the respective percentage of all histones in NET.

\begin{tabular}{cccccc}
\hline & H1 & H2A & H2B & H3 & H4 \\
\hline Amino acids & 231 & 154 & 149 & 161 & 122 \\
pI & 10.11 & 10.95 & 9.76 & 11.02 & 11.3 \\
Mass [kDa] & 20.73 & 13.99 & 13.79 & 15.27 & 11.24 \\
Basic amino acids & 66 & 30 & 31 & 33 & 27 \\
Acidic amino acids & 9 & 9 & 10 & 11 & 10 \\
Relative amount of histone [\%] ${ }^{1}$ & - & 38.02 & 34.63 & 20.97 & 6.38 \\
\hline
\end{tabular}

${ }^{1}$ The relative amount of each individual histone is based on the values for the molar amounts of histones from [7].

Successively, we incubated the individual histones with different DP of polySia, loaded them on native gels, and stained the proteins with Coomassie Blue. If the negatively charged polySia and positively charged histones interact with each other, then this interaction should result in a migration shift of histones to the positive pole. Interestingly, all of the histones showed individual migration characteristics (Figure 5).

The "linker" histone H1 (Figure 5A) migrates, as expected, to the negative pole. H1 seems to be a binding partner of polySia, as also previously described by Mishra et al. [41], and DPs higher than 23 led to a significant migration shift of $\mathrm{H} 1$.

Histone H2A and H2B show almost equal migration patterns (Figure $5 B, C$ ). Their migration is already influenced by polySia chains consisting of 15-23 sialic acid residues.

Histone $\mathrm{H} 3$ and $\mathrm{H} 4$ (Figure 5D,E) are showing the shortest migration distance. The missing staining of Coomassie Blue in case of $\mathrm{H} 3$ and $\mathrm{H} 4$ with DP $>1$ let us assume that the proteins build directly complexes with short chains, e.g., dimers, as well as oligo- and polymers, which cannot be resolved by native gel electrophoreses.

Thus, the migration capacity of all the individual histones can be influenced by distinct chain lengths of sialic acid polymers. 
negative pole

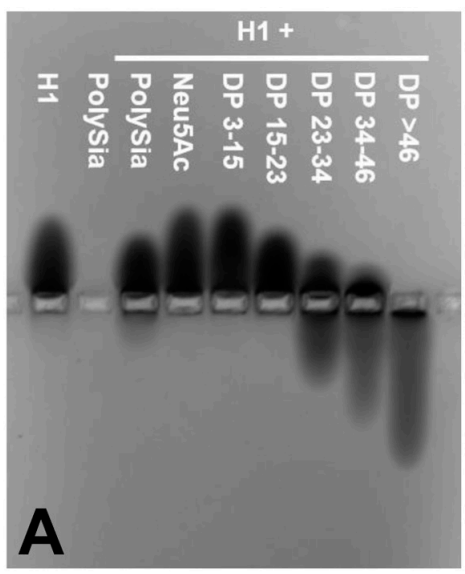

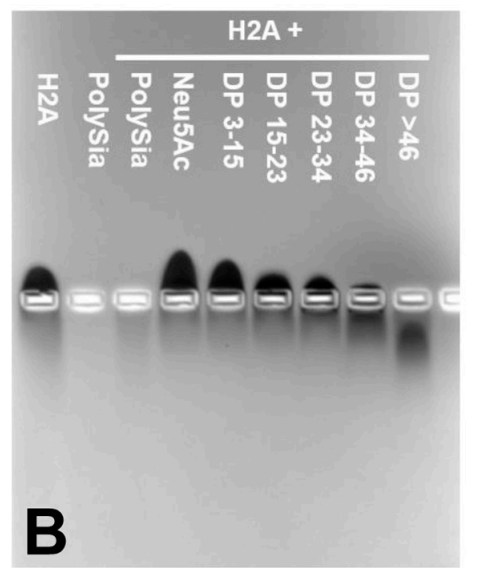

positive pole

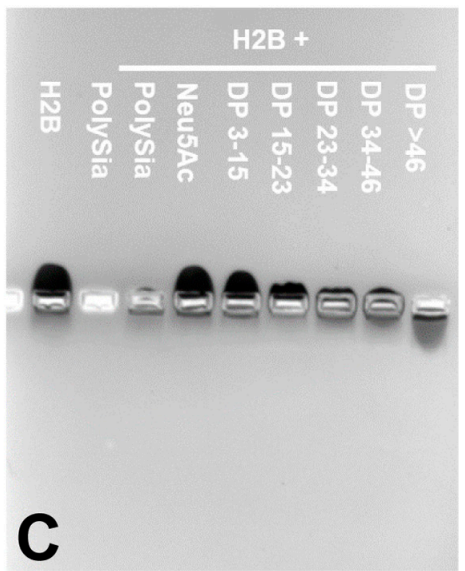

C

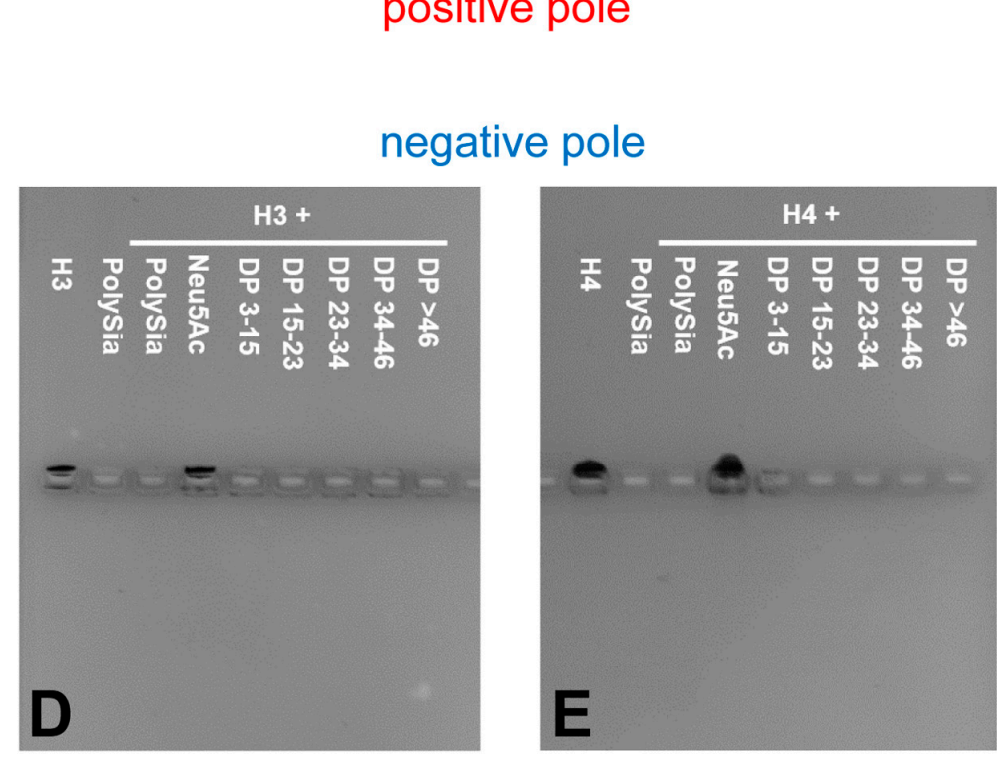

positive pole

Figure 5. Non-covalent binding assays. PolySia interacts with individual histones in a degree of polymerization (DP)-dependent manner and causes a migration-shift in native gel electrophoresis. Proteins $(5 \mu \mathrm{g})$ and a mixture or defined DP of polySia $(2.5 \mu \mathrm{g})$ were incubated, electrophoretically separated and stained with Coomasie Blue. (A) Histone H1; (B) Histone H2A; (C) Histone H2B; (D) Histone H3; (E) Histone H4. Representative gels of three independent experiments.

\subsection{Cytotoxicity Effects Are Histone-Dependent}

To examine the cytotoxicity of the individual histones, we performed cell-culture experiments. To this end, cells were treated with the individual histones (Figure 6). In parallel, we incubated cells with a mixture of histones defining this examined cytotoxicity level as $100 \%$. The results show that H1 and $\mathrm{H} 3$ are significantly less cytotoxic than the histone mix (Figure 6A,D). The observation of H1's low cytotoxicity corresponds with previous studies [7,42]. Interestingly, $\mathrm{H} 1$ could not be detected in NETs until now $[7,42]$. Probably, H1 is the first released and/or degraded histone of all, enabling the decondensation of the nucleosomes.

In contrast to $\mathrm{H} 1$ and $\mathrm{H} 3$, histone $\mathrm{H} 2 \mathrm{~A}, \mathrm{H} 2 \mathrm{~B}$, and $\mathrm{H} 4$ showed a much higher cytotoxicity when compared to the histone mix (Figure 6B,C,E). 
A

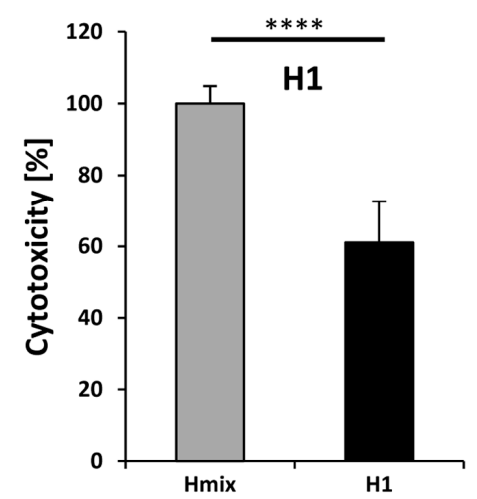

C

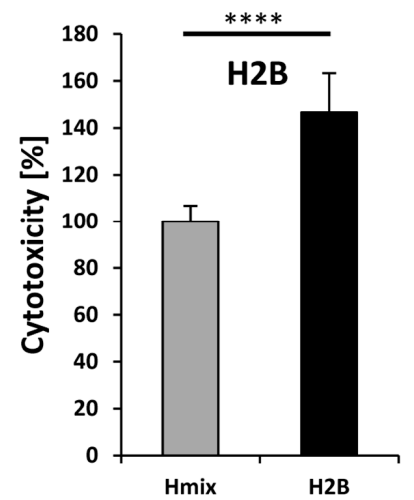

B

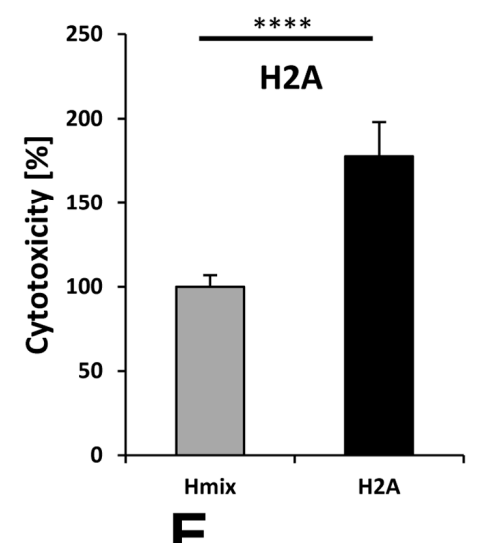

$\mathbf{E}$
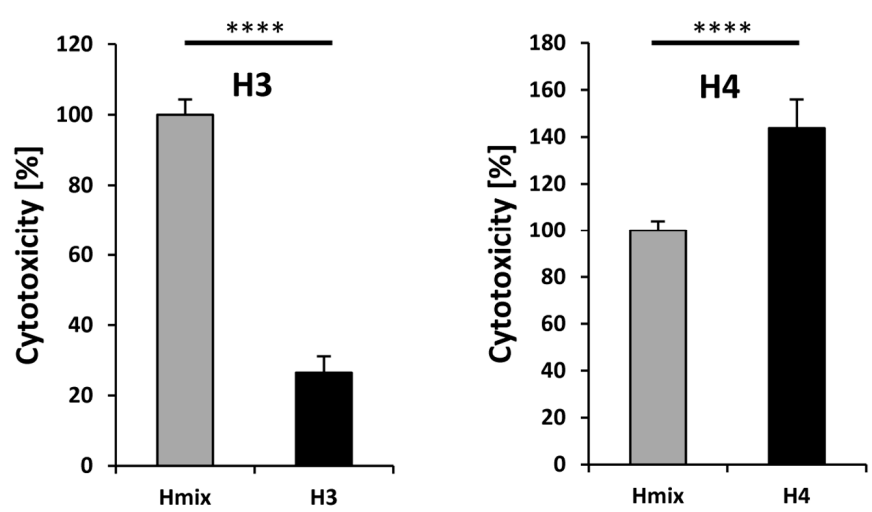

Figure 6. Cytotoxicity of individual histones compared to a mixture of histones. The cytotoxic effects of the histone mix $(60 \mu \mathrm{g} / \mathrm{mL})$ and individual histones $(60 \mu \mathrm{g} / \mathrm{mL})$ on 5B8 cells are shown. The histone-mix (gray bar) was defined as 100\%. (A) Histone H1; (B) Histone H2A; (C) Histone H2B; (D) Histone H3; and, (E) Histone H4. All of the experiments were performed three times independently. The statistical analysis was performed by $t$-test using Microsoft Excel: n.s., not significant; ${ }^{*} p<0.05$; ** $p<0.01 ;{ }^{* * *} p<0.001 ; * * * * 0.0001$.

\subsection{The Cytotoxicity of Histone H1, H2A, H2B, H3, and H4 Is Individually Influenced by PolySia}

Table 1 lists the relative amounts of individual histones in NETs, where $\mathrm{H} 2 \mathrm{~A}$ and $\mathrm{H} 2 \mathrm{~B}$ representing with up to $72 \%$ the main histone fraction (percentages were calculated using values from [7]). Their high presence and cytotoxicity make $\mathrm{H} 2 \mathrm{~A}$ and $\mathrm{H} 2 \mathrm{~B}$ to important targets in fighting the negative outcomes of NETs. We examined to which extent polySia influences the cytotoxic properties of individual histones, and determined the required chain length of polySia. For this purpose, we incubated cells with the individual histones, as well as polySia with or without defined chain lengths.

In the case of $\mathrm{H} 2 \mathrm{~A}$, only polySia chains consisting of more than 46 sialic acid residues reduce the histone-mediated cytotoxicity by up to $50 \%$ (Figure 7A). Based on the results of our migration studies using native gels, demonstrating that a DP of more than 15 units lead to migration shifts, we speculate that polySia mainly binds to those domains of $\mathrm{H} 2 \mathrm{~A}$, which do not directly influence its cytotoxicity. However, the flexible free unbound part of long polySia chains might influence its integration into the biological membrane in a negative way. 
A

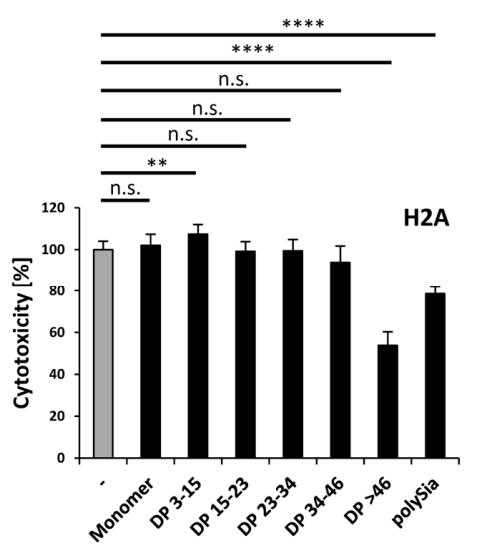

B

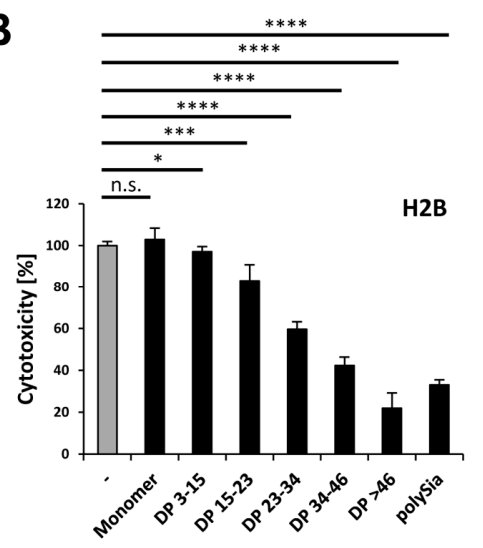

C

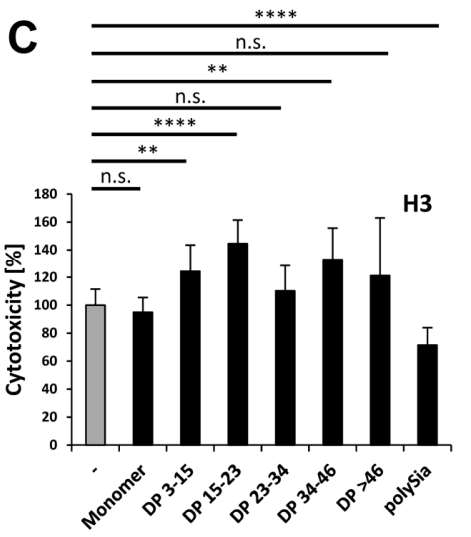

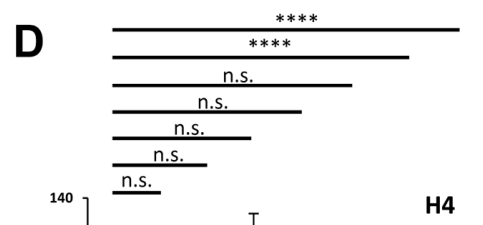

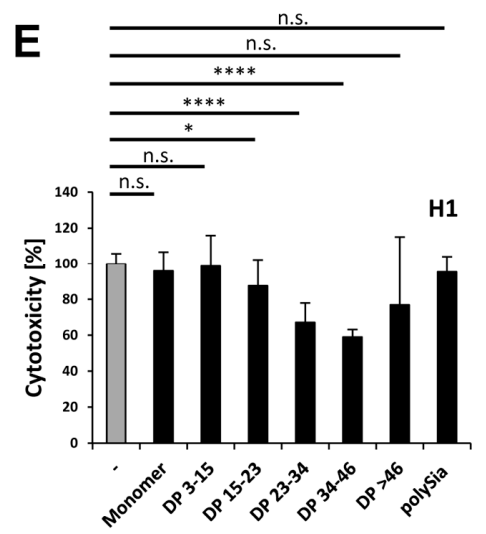

Figure 7. PolySia reduces the cytotoxicity of all histones. The cytotoxicity was determined for cells treated with each individual histone $(60 \mu \mathrm{g} / \mathrm{mL})$ alone or together with different DPs of polySia $(40 \mu \mathrm{g} / \mathrm{mL}$ ). The histone mediated cytotoxicity (gray bar) was set to $100 \%$. All effects in presence of polySia are shown in black bars. (A) Histone H2A; (B) Histone H2B; (C) Histone H3; (D) Histone H4; and, (E) Histone H1. All of the experiments were performed three times independently. The statistical analysis was performed by $t$-test using Microsoft Excel: n.s., not significant; ${ }^{*} p<0.05 ;{ }^{* *} p<0.01$; $* * * 0.001 ; * * * * 00.0001$.

H2B shows a pattern in chain length-dependent reduction of cytotoxicity, as mediated by polySia (Figure 7B) that was comparable to that of the histone mixtures published in an earlier study [32]. The cytoprotective effects of polySia on $\mathrm{H} 2 \mathrm{~B}$ reflect the results of our migration studies. Both of the experiments show the migration shift and the reduction of cytotoxicity by using increased DPs of polySia. This leads to the conclusion that polySia binds prevalently domains of $\mathrm{H} 2 \mathrm{~B}$, which are responsible for the cytotoxic effect of this histone.

Besides H2A (38.02\%) and H2B (35.63\%), H3 represents the third biggest group (20.97\%) of the histone fraction in NETs. Surprisingly, the addition of different polymer chain lengths of polySia to H3 resulted partially in increased cytotoxic values or had no effect (Figure 7C). However, unfractionated polySia decreased the cytotoxicity by up to $30 \%$ (Figure 7C).

Like $\mathrm{H} 2 \mathrm{~A}$ and $\mathrm{H} 2 \mathrm{~B}$, histone $\mathrm{H} 4$ has a higher cytotoxicity than the histone mix (Figure 6E), but is almost absent (4.4\% of all histones) in NETs (Table 1 ). Its cytotoxicity was only reduced by polySia with a DP $>46$ by up to $80 \%$ (Figure $7 D$ ). Surprisingly, this effect was reduced when unfractionated polySia was applied. Thus, shorter chains may prevent the binding of the more effective polySia chains consisting of more than 46 sialic acid residues.

Although histone $\mathrm{H} 1$ is absent in NET-fibers, the outlined experiments were also performed with H1. Here polySia chains with a DP higher than 14 were able to significantly reduce these negative effects (Figure 7E). 
As summarized in Figure 8, the cytotoxic character of all the histones can be generally influenced by polySia. However, several differences were observed in the required chain length patterns. Thus, distinct chain lengths or chain length compositions have to be used depending on the target-histone.

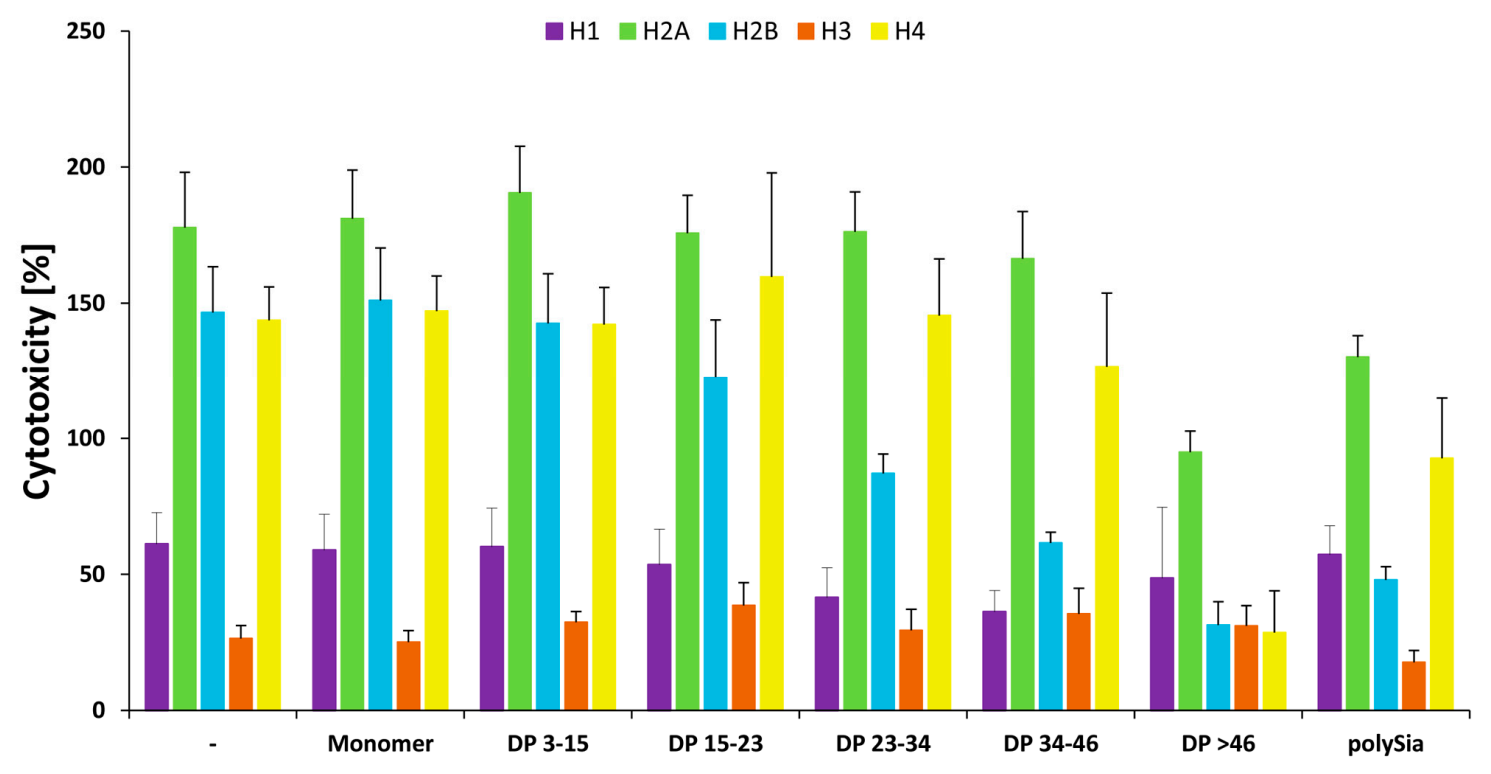

Figure 8. Summary of polySia's influence on all histones in comparison to a mixture of all histones. In contrast to Figure 7 histone-mix mediated cytotoxicity was set to $100 \%$ and compared with all individual histones. All experiments were performed three times independently.

\section{Conclusions}

In the outlined study, we demonstrated that sialic acid polymers bind to all of the individual histones. However, its binding capacity for the individual histones depends strongly on the DP. Interestingly, polySia is also able to influence the cytotoxic outcomes of all histones by the use of a distinct DP and/or a mixture of different chain length. The results strongly suggest that polySia influences the histone-cytotoxicity not just on the basis of charge alone, since the defined chain length has to be reached to modulate the cytotoxicity and/or the binding of histones. Thus, for each histone, an individual set of polySia chain length can be used to address the binding and/or cytotoxic effects of distinct histones.

For instance, it is conceivable that polySia can be used to accumulate histones on biomedical surfaces without an inactivation of its antimicrobial function. H2A is discussed to be used as a novel "antibiotic" $[43,44]$. Based on our finding it seems to be possible to accumulate H2A without influence to its toxic characteristics using polySia with a DP $<46$. Comparable strategies might also be possible with other histones, since all four core histones were already described as AMPs in pacific white shrimps [45] and oncorhyncin II, a proteolytic product of histone H1, was also suggested as an AMP in the skin of rainbow trout [46]. However, the antimicrobial and/or cytotoxic characteristics must be balanced against each other and probably defined polySia chain length settings might be helpful. Thus, the outlined results provide a further basis to develop polySia-histone based strategies for biomedical applications.

Acknowledgments: This work was supported by a grant of the Deutsche Forschungsgemeinschaft (GA 1755/1-2). The publication of this article was funded by the Open Access Fund of the Leibniz Institute for Farm Animal Biology (FBN).

Author Contributions: Kristina Zlatina and Sebastian P. Galuska conceived and designed the experiments; Kristina Zlatina performed the experiments; Kristina Zlatina, Thomas Lütteke and Sebastian P. Galuska analyzed the data; Kristina Zlatina and Sebastian P. Galuska wrote the paper. 
Conflicts of Interest: The authors declare no conflict of interest

\section{References}

1. Zawrotniak, M.; Rapala-Kozik, M. Neutrophil extracellular traps (NETs)_Formation and implications. Acta Biochim. Pol. 2013, 60, 277-284. [PubMed]

2. Miller, B.F.; Abrams, R.; Dorfman, A.; Klein, M. Antibacterial properties of protamine and histone. Science 1942, 96, 428-430. [CrossRef] [PubMed]

3. Kawasaki, H.; Iwamuro, S. Potential roles of histones in host defense as antimicrobial agents. Infect. Disord. Drug Targets 2008, 8, 195-205. [CrossRef] [PubMed]

4. Hariton-Gazal, E.; Rosenbluh, J.; Graessmann, A.; Gilon, C.; Loyter, A. Direct translocation of histone molecules across cell membranes. J. Cell Sci. 2003, 116, 4577-4586. [CrossRef] [PubMed]

5. Rosenbluh, J.; Singh, S.K.; Gafni, Y.; Graessmann, A.; Loyter, A. Non-endocytic penetration of core histones into petunia protoplasts and cultured cells: A novel mechanism for the introduction of macromolecules into plant cells. Biochim. Biophys. Acta 2004, 1664, 230-240. [CrossRef] [PubMed]

6. Hancock, R.E.; Patrzykat, A. Clinical development of cationic antimicrobial peptides: From natural to novel antibiotics. Curr. Drug Targets Infect. Disord. 2002, 2, 79-83. [CrossRef] [PubMed]

7. Urban, C.F.; Ermert, D.; Schmid, M.; Abu-Abed, U.; Goosmann, C.; Nacken, W.; Brinkmann, V.; Jungblut, P.R.; Zychlinsky, A. Neutrophil extracellular traps contain calprotectin, a cytosolic protein complex involved in host defense against candida albicans. PLoS Pathog 2009, 5, e1000639. [CrossRef] [PubMed]

8. Parseghian, M.H.; Luhrs, K.A. Beyond the walls of the nucleus: The role of histones in cellular signaling and innate immunity. Biochem. Cell Biol. 2006, 84, 589-604. [CrossRef] [PubMed]

9. Xu, J.; Zhang, X.; Monestier, M.; Esmon, N.L.; Esmon, C.T. Extracellular histones are mediators of death through TLR2 and TLR4 in mouse fatal liver injury. J. Immunol. 2011, 187, 2626-2631. [CrossRef] [PubMed]

10. Iwasaki, A.; Medzhitov, R. Toll-like receptor control of the adaptive immune responses. Nat. Immunol. 2004, 5, 987-995. [CrossRef] [PubMed]

11. Krieg, A.M. Toll-like receptor 9 (TLR9) agonists in the treatment of cancer. Oncogene 2008, 27, 161-167. [CrossRef] [PubMed]

12. Boe, D.M.; Curtis, B.J.; Chen, M.M.; Ippolito, J.A.; Kovacs, E.J. Extracellular traps and macrophages: New roles for the versatile phagocyte. J. Leukoc. Biol. 2015, 97, 1023-1035. [CrossRef] [PubMed]

13. Leffler, J.; Martin, M.; Gullstrand, B.; Tyden, H.; Lood, C.; Truedsson, L.; Bengtsson, A.A.; Blom, A.M. Neutrophil extracellular traps that are not degraded in systemic lupus erythematosus activate complement exacerbating the disease. J. Immunol. 2012, 188, 3522-3531. [CrossRef] [PubMed]

14. Peng, S.; Li, C.; Wang, X.; Liu, X.; Han, C.; Jin, T.; Liu, S.; Zhang, X.; Zhang, H.; He, X.; et al. Increased toll-like receptors activity and TLR ligands in patients with autoimmune thyroid diseases. Front. Immunol. 2016, 7, 578. [CrossRef] [PubMed]

15. Villanueva, E.; Yalavarthi, S.; Berthier, C.C.; Hodgin, J.B.; Khandpur, R.; Lin, A.M.; Rubin, C.J.; Zhao, W.; Olsen, S.H.; Klinker, M.; et al. Netting neutrophils induce endothelial damage, infiltrate tissues, and expose immunostimulatory molecules in systemic lupus erythematosus. J. Immunol. 2011, 187, 538-552. [CrossRef] [PubMed]

16. Kessenbrock, K.; Krumbholz, M.; Schonermarck, U.; Back, W.; Gross, W.L.; Werb, Z.; Grone, H.J.; Brinkmann, V.; Jenne, D.E. Netting neutrophils in autoimmune small-vessel vasculitis. Nat. Med. 2009, 15, 623-625. [CrossRef] [PubMed]

17. Von Bruhl, M.L.; Stark, K.; Steinhart, A.; Chandraratne, S.; Konrad, I.; Lorenz, M.; Khandoga, A.; Tirniceriu, A.; Coletti, R.; Kollnberger, M.; et al. Monocytes, neutrophils, and platelets cooperate to initiate and propagate venous thrombosis in mice in vivo. J. Exp. Med. 2012, 209, 819-835. [CrossRef] [PubMed]

18. Clark, S.R.; Ma, A.C.; Tavener, S.A.; McDonald, B.; Goodarzi, Z.; Kelly, M.M.; Patel, K.D.; Chakrabarti, S.; McAvoy, E.; Sinclair, G.D.; et al. Platelet TLR4 activates neutrophil extracellular traps to ensnare bacteria in septic blood. Nat. Med. 2007, 13, 463-469. [CrossRef] [PubMed]

19. Marcos, V.; Zhou, Z.; Yildirim, A.O.; Bohla, A.; Hector, A.; Vitkov, L.; Wiedenbauer, E.M.; Krautgartner, W.D.; Stoiber, W.; Belohradsky, B.H.; et al. CXCR2 mediates nadph oxidase-independent neutrophil extracellular trap formation in cystic fibrosis airway inflammation. Nat. Med. 2010, 16, 1018-1023. [CrossRef] [PubMed] 
20. Saffarzadeh, M.; Juenemann, C.; Queisser, M.A.; Lochnit, G.; Barreto, G.; Galuska, S.P.; Lohmeyer, J.; Preissner, K.T. Neutrophil extracellular traps directly induce epithelial and endothelial cell death: A predominant role of histones. PLoS ONE 2012, 7, e32366. [CrossRef] [PubMed]

21. Ulm, C.; Saffarzadeh, M.; Mahavadi, P.; Müller, S.; Prem, G.; Saboor, F.; Simon, P.; Middendorff, R.; Geyer, H.; Henneke, I.; et al. Soluble polysialylated NCAM: A novel player of the innate immune system in the lung. Cell. Mol. Life Sci. 2013, 70, 3695-3708. [CrossRef] [PubMed]

22. Galuska, C.E.; Lutteke, T.; Galuska, S.P. Is polysialylated ncam not only a regulator during brain development but also during the formation of other organs? Biology 2017, 6, 27. [CrossRef] [PubMed]

23. Colley, K.J.; Kitajima, K.; Sato, C. Polysialic acid: Biosynthesis, novel functions and applications. Crit. Rev. Biochem. Mol. Biol. 2014, 49, 498-532. [CrossRef] [PubMed]

24. Schnaar, R.L.; Gerardy-Schahn, R.; Hildebrandt, H. Sialic acids in the brain: Gangliosides and polysialic acid in nervous system development, stability, disease, and regeneration. Physiol. Rev. 2014, 94, 461-518. [CrossRef] [PubMed]

25. Werneburg, S.; Buettner, F.F.; Erben, L.; Mathews, M.; Neumann, H.; Muhlenhoff, M.; Hildebrandt, H. Polysialylation and lipopolysaccharide-induced shedding of e-selectin ligand-1 and neuropilin-2 by microglia and THP-1 macrophages. Glia 2016, 64, 1314-1330. [CrossRef] [PubMed]

26. Wang, Y.; Neumann, H. Alleviation of neurotoxicity by microglial human Siglec-11. J. Neurosci. 2010, 30, 3482-3488. [CrossRef] [PubMed]

27. Shahraz, A.; Kopatz, J.; Mathy, R.; Kappler, J.; Winter, D.; Kapoor, S.; Schutza, V.; Scheper, T.; Gieselmann, V.; Neumann, H. Anti-inflammatory activity of low molecular weight polysialic acid on human macrophages. Sci. Rep. 2015, 5, 16800. [CrossRef] [PubMed]

28. Curreli, S.; Arany, Z.; Gerardy-Schahn, R.; Mann, D.; Stamatos, N.M. Polysialylated neuropilin-2 is expressed on the surface of human dendritic cells and modulates dendritic cell-T lymphocyte interactions. J. Biol. Chem. 2007, 282, 30346-30356. [CrossRef] [PubMed]

29. Stamatos, N.M.; Zhang, L.; Jokilammi, A.; Finne, J.; Chen, W.H.; El-Maarouf, A.; Cross, A.S.; Hankey, K.G. Changes in polysialic acid expression on myeloid cells during differentiation and recruitment to sites of inflammation: Role in phagocytosis. Glycobiology 2014, 24, 864-879. [CrossRef] [PubMed]

30. Kiermaier, E.; Moussion, C.; Veldkamp, C.T.; Gerardy-Schahn, R.; de Vries, I.; Williams, L.G.; Chaffee, G.R.; Phillips, A.J.; Freiberger, F.; Imre, R.; et al. Polysialylation controls dendritic cell trafficking by regulating chemokine recognition. Science 2016, 351, 186-190. [CrossRef] [PubMed]

31. Simon, P.; Bäumner, S.; Busch, O.; Röhrich, R.; Kaese, M.; Richterich, P.; Wehrend, A.; Müller, K.; Gerardy-Schahn, R.; Mühlenhoff, M.; et al. Polysialic acid is present in mammalian semen as a post-translational modification of the neural cell adhesion molecule ncam and the polysialyltransferase ST8Siaii. J. Biol. Chem. 2013, 288, 18825-18833. [CrossRef] [PubMed]

32. Galuska, S.P.; Galuska, C.E.; Tharmalingam, T.; Zlatina, K.; Prem, G.; Husejnov, F.C.O.; Rudd, P.M.; Vann, W.F.; Reid, C.; Vionnet, J.; et al. In vitro generation of polysialylated cervical mucins by bacterial polysialyltransferases to counteract cytotoxicity of extracellular histones. FEBS J. 2017, 284, 1688-1699. [CrossRef] [PubMed]

33. Galuska, C.E.; Dambon, J.A.; Kuhnle, A.; Bornhofft, K.F.; Prem, G.; Zlatina, K.; Lutteke, T.; Galuska, S.P. Artificial polysialic acid chains as sialidase-resistant molecular-anchors to accumulate particles on neutrophil extracellular traps. Front. Immunol. 2017, 8, 1229. [CrossRef] [PubMed]

34. Osley, M.A. Epigenetics: How to lose a tail. Nature 2008, 456, 885-886. [CrossRef] [PubMed]

35. Hara, S.; Yamaguchi, M.; Takemori, Y.; Furuhata, K.; Ogura, H.; Nakamura, M. Determination of mono- $\mathrm{O}$-acetylated $\mathrm{N}$-acetylneuraminic acids in human and rat sera by fluorometric high-performance liquid chromatography. Anal. Biochem. 1989, 179, 162-166. [CrossRef]

36. Hara, S.; Takemori, Y.; Yamaguchi, M.; Nakamura, M.; Ohkura, Y. Fluorometric high-performance liquid chromatography of $\mathrm{N}$-acetyl- and $\mathrm{N}$-glycolylneuraminic acids and its application to their microdetermination in human and animal sera, glycoproteins, and glycolipids. Anal. Biochem. 1987, 164, 138-145. [CrossRef]

37. Galuska, S.P.; Geyer, H.; Weinhold, B.; Kontou, M.; Röhrich, R.C.; Bernard, U.; Gerardy-Schahn, R.; Reutter, W.; Münster-Kuhnel, A.; Geyer, R. Quantification of nucleotide-activated sialic acids by a combination of reduction and fluorescent labeling. Anal. Chem. 2010, 82, 4591-4598. [CrossRef] [PubMed] 
38. Bartel, J.; Feuerstacke, C.; Galuska, C.E.; Weinhold, B.; Gerardy-Schahn, R.; Geyer, R.; Munster-Kuhnel, A.; Middendorff, R.; Galuska, S.P. Laser microdissection of paraffin embedded tissue as a tool to estimate the sialylation status of selected cell populations. Anal. Chem. 2014, 86, 2326-2331. [CrossRef] [PubMed]

39. Wu, M.; Kusukawa, N. Sds agarose gels for analysis of proteins. Biotechniques 1998, 24, 676-678. [PubMed]

40. Kim, R.; Yokota, H.; Kim, S.H. Electrophoresis of proteins and protein-protein complexes in a native agarose gel. Anal. Biochem. 2000, 282, 147-149. [CrossRef] [PubMed]

41. Mishra, B.; von der Ohe, M.; Schulze, C.; Bian, S.; Makhina, T.; Loers, G.; Kleene, R.; Schachner, M. Functional role of the interaction between polysialic acid and extracellular histone H1. J. Neurosci. 2010, 30, 12400-12413. [CrossRef] [PubMed]

42. Papayannopoulos, V.; Metzler, K.D.; Hakkim, A.; Zychlinsky, A. Neutrophil elastase and myeloperoxidase regulate the formation of neutrophil extracellular traps. J. Cell Biol. 2010, 191, 677-691. [CrossRef] [PubMed]

43. Cho, J.H.; Sung, B.H.; Kim, S.C. Buforins: Histone H2A-derived antimicrobial peptides from toad stomach. Biochim. Biophys. Acta 2009, 1788, 1564-1569. [CrossRef] [PubMed]

44. Koo, Y.S.; Kim, J.M.; Park, I.Y.; Yu, B.J.; Jang, S.A.; Kim, K.S.; Park, C.B.; Cho, J.H.; Kim, S.C. Structure-activity relations of parasin i, a histone H2A-derived antimicrobial peptide. Peptides 2008, 29, 1102-1108. [CrossRef] [PubMed]

45. Patat, S.A.; Carnegie, R.B.; Kingsbury, C.; Gross, P.S.; Chapman, R.; Schey, K.L. Antimicrobial activity of histones from hemocytes of the pacific white shrimp. Eur. J. Biochem. 2004, 271, 4825-4833. [CrossRef] [PubMed]

46. Fernandes, J.M.; Molle, G.; Kemp, G.D.; Smith, V.J. Isolation and characterisation of oncorhyncin II, a histone H1-derived antimicrobial peptide from skin secretions of rainbow trout, oncorhynchus mykiss. Dev. Comp. Immunol. 2004, 28, 127-138. [CrossRef]

(C) 2017 by the authors. Licensee MDPI, Basel, Switzerland. This article is an open access article distributed under the terms and conditions of the Creative Commons Attribution (CC BY) license (http:/ / creativecommons.org/licenses/by/4.0/). 